\title{
Pengetahuan Ibu tentang Sibling Rivalry dengan Pola Asuh Ibu pada Anak Balita
}

\author{
Knowledge of Mother About Sibling Rivalry With Mother's Parenting Pattern In Children Under Five
}

\author{
Farida Yuliani* \\ Program Studi D-III Kebidanan, STIKes Majapahit Mojokerto, Jawa Timur \\ *Corresponding author : farida_yuliani80@yahoo.co.id
}

\begin{abstract}
ABSTRAK
Perasaan cemburu dan benci yang biasanya dialami oleh seorang anak terhadap kehadiran saudara kandungnya menjadi permasalahan khusus dalam keluarga, karena kita adalah mahkluk sosial yang menuntut manusia hidup bermasyarakat. Penelitian ini bertujuan untuk mengetahuibagaimana pengetahuan ibu tentang sibling rivalry dengan pola asuh ibu pada anak balita di Paud Tarbiyatus Syibyan

Penelitian ini merupakan penelitian analitik cross sectional. Variabel independen dalam penelitian ini adalah pengetahuan ibu tentang sibling rivalry, sedangkan variabel dependennya adalah pola asuh ibu pada anak balita. Populasi dalam penelitian ini adalah semua ibu yang memiliki dua anak balita di Paud Tarbiyatus Syibyan sebanyak 41 ibu balita.Sampel sebanyak 34 responden yang diambil dengan Total Sampling. Penelitian ini dilakukan pada bulan Februari 2018. Instrumen yang dipakai adalah kuesioner dan checklist dan analisa data menggunakan uji wilcoxon sign rank test.

Hasil penelitian menunjukkan dari 34 responden, hampir setengah dari responden adalah berpengetahuan cukup, yaitu 17 orang (50\%) dan hampir seluruh responden memberikan pola asuh demokratis, yaitu 21 responden (61,8\%).

Analisis uji Wilcoxon derajat kemaknaan 0,05 didapatkan nilai signifikansi 0,006, sehingga nilai 0,006<0,05 yang berarti $H_{0}$ ditolak dan $H 1$ diterima artinya ada hubungan pengetahuan ibu tentang sibling rivalry dengan pola asuh ibu pada anak balita di Paud Tarbiyatus Syibyan.

Pengetahuan yang baik akan memotivasi ibu untuk memberikan pola asuh demokratis kepada anaknya. oleh karena itu hasil penelitian ini dapat digunakan sebagai motivasi supaya ibu meningkatkan pengetahuannya tentang sibling rivalry dan diharapkan ibu memberikan pola asuh yang terbaik bagi anaknya sehingga kejadian sibling rivalry di dalam keluarga dapat terhindarkan.
\end{abstract}

Kata kunci: pengetahuan, pola asuh, ibu balita

\section{ABSTRACT}

The feelings of jealousy and hatred that a child usually suffers from the presence of his siblings become a special problem in the family, because we are social beings that demand people to live in society. This study aims to find out how knowledge of mother about sibling rivalry with mother's parenting pattern in children under five in Paud Tarbiyatus Syibyan

This research is cross sectional analytic research. Independent variable in this research is mother's knowledge about sibling rivalry, while the dependent variable is mother's parenting pattern in children under five. The population in this study were all mothers who had two children under five in Paud Tarbiyatus Syibyan as many as 41 mothers under five. Samples were 34 respondents taken with Total Sampling. This research was conducted in February 2018. The instruments used were questionnaires and checklists and data analysis using the test wilcoxon sign rank test.

The result of the research shows that from 34 respondents, almost half of the respondents are knowledgeable enough, that is 17 people (50\%) and almost all respondents give democratic parenting, that is 21 respondents $(61,8 \%)$.

Wilcoxon test analysis significance level of 0.05 obtained significance value 0.006, so the value of $0.006<0.05$ which means $\mathrm{HO}$ rejected and $\mathrm{H} 1$ accepted means there is a relationship knowledge of mother about sibling rivalry with mother's parenting pattern in children under five in Paud Tarbiyatus Syibyan.

Good knowledge will motivate mothers to provide their children with democratic parenting. therefore the results of this study can be used as a motivation so that mothers increase knowledge about sibling rivalry and expected mother provide the best parenting pattern for his child so that the incidence of sibling rivalry in the family can be avoided.

Keywords: Knowledge, Patterns, Toddler 


\section{PENDAHULUAN}

Perasaan cemburu yang biasanya dialami oleh seorang anak terhadap kehadiran saudara kandungnya menjadi permasalahan tersendiri dalam keluarga. Meskipun ruang lingkupnya kecil, keluarga adalah kumpulan orang, persaingan antara saudara kandung otomatis tidak bisa dihindarkan, baik positif ataupun negatif. Setiawati, 2008 mengatakan sibling rivalry lazim terjadi pada usia antara 1-3 tahun dan muncul pada usia 3-5 tahun kemudian muncul kembali pada usia 8-12 tahun karena kehadiran adik dianggap menyita waktu dan perhatian terlalu banyak.

Seorang psikolog Shofiana pada tahun 2008 memperoleh data dari dua tempat yang diteliti, di Pekalongan diperoleh $68,5 \%$ anak mengalami sibling rivalry dari 80 anak.

Berdasarkan studi pendahuluan yang dilakukan di TK Dharma wanita terhadap 8 orang ibu diperoleh data pengetahuan tentang sibling rivalry dalam kriteria cukup sebanyak 2 orang (25\%), kurang 5 orang $(62,5 \%)$, dan 1 orang memiliki pengetahuan baik (12,5\%). Selain itu, juga didapatkan data pola asuh ibu pada anak balita sebagai berikut. Ibu yang menggunakan pola asuh otoriter sebanyak 2 orang (25\%) yang mana mereka lebih sering memarahi anak saat anak melakukan kesalahan. Ibu dengan pola asuh permisif sebanyak 1 orang (12,5\%) yang mana mereka lebih sering membiarkan anak melakukan apa yang mereka inginkan dan menganggap bahwa kenakalan anak kecil adalah hal biasa, dan terdapat 4 orang ibu (50\%) yang menggunakan pola asuh demokratis yaitu mengarahkan dan memberikan penjelasan kepada anak saat mereka melakukan kesalahan. Serta pola asuh penelantar ada 1 orang $(12,5 \%)$

Rasa cemburu/persaingan antar saudara kandung dapat menimbulkan kemunduran tingkah laku ke tahap sebelumnya yaitu dengan mengompol di celana, antisosial, cari perhatian dengan sengaja bertingkah nakal, melawan orang tua, dan menjadi cengeng (Thompson,
2003). Sibling rivalry dapat menyebabkan luka yang paling dalam di lubuk hati seseorang, apalagi jika orang tersebut introvet, tertutup, semua kejengkelan, kemarahan akan tersimpan begitu saja di hati tapi pada suatu saat tertentu bila kebetulan ada pemicu yang tepat, tekanan tersebut dapat menjadi suatu ledakan kemarahan yang hebat dan bahkan tidak terpikirkan sebelumnya. Jika si anak tidak kuat mentalnya, bukan tidak mungkin hal ini menjadi suatu "penyakit" atau kelainan mental (Puti, 2008).

Seorang ibu harus memperhatikan pertumbuhan dan perkembangan anaknya, bagaimana kiat-kiat menghindari sibling rivalry dan penanganannya. Pengetahuan yang baru dapat diperoleh seseorang dengan adanya kemudahan fasilitas dan informasi (Suparyanto, 2011). Peran tenaga kesehatan adalah harus mampu menghindarkan kejadian sibling rivalry dengan cara memberikan suatu pengetahuan melalui penyuluhan di posyandu serta di masyarakat bahwa dampak dari sibling rivalry itu sangat besar terhadap perkembangan anak, serta sibling rivalry ini dapat juga dihindarkan dengan pola asuh yang benar sehingga anak dapat tumbuh dan berkembang sesuai dengan tingkat perkembangannya.

\section{METODE PENELITIAN}

Jenis penelitian yang digunakan dalam penelitian ini adalah penelitian analitik dengan rancang bangun penelitiannya menggunakan metode pendekatan cross sectional. Dalam penelitian ini yang merupakan faktor efek adalah pola asuh ibu pada anak balita dan faktor risikonya adalah pengetahuan ibu. Populasi dalam penelitian adalah ibu yang memiliki anak lebih dari satu di Paud Tarbiyatus Syibyan sebanyak 34 orang. Untuk variabel pengetahuan dilakukan dengan menggunakan kuesioner dengan menggunakan skala Gutmann. Pengumpulan variabel pola asuh juga menggunakan kuesioner. Kedua variabel dilakukan uji Wilcoxon Signed Rank. 


\section{HASIL PENELITIAN}

Berdasarkan Tabel 1 bahwa rata-rata responden berusia antara 20-35 tahun yaitu sebanyak 21 orang $(61,8 \%)$.

Berdasarkan Tabel 2 bahwa sebagian kecil responden (ibu) lulusan pendidikan dasar yaitu sebanyak 29 orang $(55,9 \%)$.

Berdasarkan Tabel 3 bahwa rata-rata responden tidak bekerja yaitu sebanyak 22 orang $(64,7 \%)$.

Berdasarkan Tabel 4 bahwa sebagian kecil responden berpengetahuan cukup tentang sibling rivalry, sebanyak 17 orang (50\%).

Berdasarkan Tabel 5 menunjukkan bahwa rata-rata responden menerapkan pola asuh demokratis sebanyak 25 orang $(69,4 \%)$.

Berdasarkan Tabel 6 di atas dapat diketahui bahwa sebagian kecil responden berpengetahuan cukup tentang sibling rivalry yaitu 17 orang $(50,0 \%)$ dan rata rata responden memilih pola asuh demokratis yaitu 21 orang $(61,8 \%)$. Hasil tabel tabulasi silang, selanjutnya dilakukan perhitungan uji Wilcoxon dengan bantuan SPSS for windows. Hasil uji Wilcoxon derajat kemaknaan 0,05 didapatkan nilai signifikansi 0,006 , sehingga nilai $0,006<0,05$ yang berarti $\mathrm{H}_{0}$ ditolak dan $\mathrm{H} 1$ diterima artinya ada hubungan pengetahuan ibu tentang sibling rivalry dengan pola asuh ibu pada anak balita.

Tabel 1 Distribusi karakteristik responden berdasarkan umur

\begin{tabular}{|c|l|c|c|}
\hline No & Kelompok umur & Frekuensi & Prosentase \\
\hline 1 & $<20$ tahun & 0 & 0 \\
2 & $20-35$ tahun & 21 & 61,8 \\
3 & $>35$ tahun & 13 & 38,2 \\
\hline \multicolumn{2}{|c|}{ Total } & 34 & 100 \\
\hline
\end{tabular}

Table 2. Distribusi karakteristik responden berdasarkan pendidikan

\begin{tabular}{|c|l|c|c|}
\hline No & Pendidikan & Frekuensi & Prosentase \\
\hline 1 & SD & 15 & 44,1 \\
2 & SMP & 10 & 29,4 \\
3 & SMA & 7 & 20,6 \\
4 & PT & 2 & 5,9 \\
\hline Total & & 34 & 100 \\
\hline
\end{tabular}

Table 3. Distribusi karakteristik responden berdasarkan pekerjaan

\begin{tabular}{|c|l|c|c|}
\hline No & Pekerjaan & Frekuensi & Prosentase \\
\hline 1 & Bekerja & 12 & 35,3 \\
2 & Tidak bekerja & 22 & 64,7 \\
\hline & Total & 34 & 100 \\
\hline
\end{tabular}

Table 4. Distribusi responden berdasarkan pengetahuan

\begin{tabular}{|l|l|c|c|}
\hline No & Kriteria & $\begin{array}{c}\text { Jumlah } \\
\text { responden }\end{array}$ & $\begin{array}{c}\text { Prosentase } \\
(\mathbf{\%})\end{array}$ \\
\hline 1 & Baik & 9 & 26,5 \\
2 & Cukup & 17 & 50 \\
3 & Kurang & 8 & 23,5 \\
\hline & Total & 34 & 100 \\
\hline
\end{tabular}

Tabel 5 Distribusi responden menurut pola asuh

\begin{tabular}{|l|l|c|c|}
\hline No & Kriteria & $\begin{array}{c}\text { Jumlah } \\
\text { responden }\end{array}$ & $\begin{array}{c}\text { Prosentase } \\
(\mathbf{\%})\end{array}$ \\
\hline 1 & Otoriter & 5 & 14,7 \\
2 & Permisif & 8 & 23,5 \\
3 & Demokratis & 21 & 61,8 \\
4 & Campuran & 0 & 0 \\
\hline \multicolumn{2}{|c|}{ Total } & 34 & 100 \\
\hline
\end{tabular}

Tabel 6 Tabulasi silang pengaruh jarak kelahiran anak dengan status gizi Balita

\begin{tabular}{|l|l|c|c|c|c|c|c|c|c|c|c|}
\hline \multirow{2}{*}{ No } & Pengetahuan & \multicolumn{9}{|c|}{ Pola asuh } & \multicolumn{2}{c|}{ Total } \\
\cline { 3 - 12 } & & Demokratis & \multicolumn{2}{|c|}{ Permisif } & Otoriter & \multicolumn{2}{c|}{ Campuran } & \multicolumn{2}{c|}{} \\
\cline { 3 - 12 } & & $\mathrm{F}$ & $\%$ & $\mathrm{~F}$ & $\%$ & $\mathrm{~F}$ & $\%$ & $\mathrm{~F}$ & $\%$ & $\mathrm{~F}$ & $\%$ \\
\hline 1 & Baik & 7 & 20,6 & 1 & 2,9 & 1 & 2,9 & 0 & 0 & 9 & 26,5 \\
\hline 2 & Cukup & 13 & 38,2 & 2 & 5,9 & 2 & 5,9 & 0 & 0 & 17 & 50,0 \\
\hline 3 & Kurang & 1 & 2,9 & 5 & 14,7 & 2 & 5,9 & 0 & 0 & 8 & 23,5 \\
\hline & & 21 & 61,8 & 8 & 23,5 & 5 & 14,7 & 0 & 0 & 34 & 100 \\
\hline
\end{tabular}




\section{PEMBAHASAN}

\section{Pengetahuan}

Hampir seluruh responden yang berpengetahuan cukup mampu menjawab pertanyaan tentang pengertian sibling rivalry dengan benar. Hal ini disebabkan responden mampu menganalogikannya dengan pertanyaanpertanyaan yang lain (pengetahuan melalui jalan pikiran) meskipun istilah tersebut belum diketahui benar oleh mereka. Sebagian besar responden berpengetahuan cukup tidak dapat menjawab pertanyaan tersebut mungkin karena responden belum mengerti sepenuhnya tentang pengertian sibling rivalry sehingga mereka sulit membedakan mana pengertian yang benar dan mana yang salah karena kedua definisi yang tercantum memiliki makna yang hampir sama. Ibu yang berpengetahuan cukup menganggap sibling rivalry timbul jika ibu memarahi sang kakak sehingga menyebabkan kakak benci pada si adik.Kebanyakan dari mereka masih belum mengetahui bahwa sibling rivalry bisa berdampak pada perkembangan anak selanjutnya dalam keluarga. Namun demikian, ibu yang berpengetahuan cukup telah banyak yang mampu mengatasi sibling rivalry. Pada aspek psikologis atau mental taraf berpikir seseorang semakin matang dan dewasa. Usia 20-35 tahun termasuk usia dewasa, sehingga memungkinkan lebih banyak menerima informasi dan pengalaman sehingga pengetahuan yang dimiliki bertambah. Dengan usia yang matang ibu banyak mendapatkan pengetahuan tentang sibling rivalry pada anak, baik dari pengalaman pribadi maupun informasi dari pengalaman teman atau tetangga sehingga menambah pengetahuan ibu. Responden yang berpengetahuan baik dapat menjawab dengan benar pada hampir seluruh pertanyaan. Ibu yang berpengetahuan baik mengetahui bahwa kelahiran bayi baru dapat menyebabkan sibling rivalry dan sifat ibu membanding-bandingkan anak dapat mempengaruhi sibling rivalry pada anak. Selain itu, ibu yang berpengetahuan baik juga banyak yang telah mengetahui dampak dari sibling rivalry. Mereka menyatakan bahwa anak yang terus bersaing dan saling mendengki sampai dewasa merupakan dampak dari sibling rivalry. Banyak dari mereka juga berpendapat bahwa anak boleh dilibatkan untuk membantu mempersiapkan keperluan adik untuk mencegah timbulnya sibling rivalry. Pengetahuan ibu dalam kategori baik ini mungkin dikarenakan mereka mendapatkan pengetahuan tersebut dari berbagi pengalaman dengan teman. Hal ini juga bisa dikarenakan responden memang mengetahui tentang sibling rivalry dari lingkungan misalnya dari kader atau tenaga kesehatan atau dari media-media informasi lainnya.

Berdasarkan data tabulasi silang antara pekerjaan dengan pengetahuan didapatkan sebagian besar responden bekerja memiliki pengetahuan baik dan cukup tentang sibling rivalry yaitu masing masing 5 orang 10 responden. Namun, didapatkan pula bahwa sebagian besar responden berpengetahuan kurang berasal dari responden yang tidak bekerja yaitu 6 responden. Menurut Mubarak (2007) lingkungan pekerjaan dapat menjadikan seseorang memperoleh pengalaman dan pengetahuan baik secara langsung maupun secara tidak langsung. Bila tidak bekerja maka pengetahuan yang diperoleh hanya dari sekitar rumah saja, sedangkan bila bekerja, maka informasi yang diperoleh lebih banyak dari pengalaman teman kerja, karena teman kerja merupakan salah satu seseorang yang dianggap penting, seseorang yang dapat diajak bertukar pikiran dan pengalaman, terutama dalam menghadapi sibling rivalry pada anak.

\section{Pola Asuh Pada Anak Balita}

Berdasarkan data diperoleh bahwa rata rata responden memilih pola asuh demokratis yaitu sebanyak 21 orang $(61,8 \%)$, pola asuh permisif yaitu 8 orang $(23,5 \%)$ yang memilih pola asuh otoriter 5 orang $(14,7 \%)$.

Pola asuh adalah bagaimana orang tua 
memperlakukan seorang anak untuk dapat menjadi bagian dari masyarakat yang baik dan bertanggung jawab. Keluarga adalah tempat pendidikan utama dalam pengasuhan anak karena dalam keluarga terdapat interaksi langsung antara anak dan orang tua. Interaksi tersebut mencakup perawatan seperti dan mencukupi kebutuhan makan, mendorong keberhasilan dan melindungi, maupun sosialiasi yaitu mengajarkan tingkah laku umum yang diterima oleh masyarakat (Wiwit, 2003). Menurut Surbakti, (2009) pola asuh demokratis memberikan manfaat kepada keluarga dan anak karena melalui pola asuh ini setiap anak dan anggota keluarga lainnya akan belajar menghargai pendapat orang lain, menghormati perbedaan pendapat, memupuk persaudaraan dan persahabatan, mengedepankan sikap tenggang rasa dan membangun kerja sama. Dengan demikian ibu dapat mencegah dan mengatasi timbulnya sibling rivalry pada anak balitanya. Ibu dengan pola asuh demokratis cenderung menuntut namun peka terhadap anak. Ibu dengan pola asuh ini lebih banyak menunjukkan sisi positif daripada ibu dengan pendekatan otoriter dan permisif dengan meletakkan aturan dan menjaga komunikasi tetap terbuka sesuai dengan arahan mereka (Daron, 2005).

\section{Hubungan pengetahuan ibu tentang si-} bling rivalry dengan pola asuh ibu pada anak balita

Berdasarkan tabel tabulasi silang dapat diketahui bahwa sebagian kecil responden berpengetahuan cukup tentang sibling rivalry yaitu 17 responden $(50,0 \%)$ dan rata rata responden memilih pola asuh demokratis yaitu 21 responden $(61,48)$. Hasil tabel tabulasi silang, selanjutnya dilakukan perhitungan uji Wilcoxon dengan bantuan SPSS v16 for windows. Hasil uji Wilcoxon dengan derajat kemaknaan 0,05 didapatkan nilai signifikansi 0,006 , sehingga nilai $0,006<0,05$ yang berarti $\mathrm{H}_{0}$ ditolak dan $\mathrm{H} 1$ diterima artinya ada hubungan pengetahuan ibu tentang sibling rivalry dengan pola asuh ibu pada anak balita.

Berdasarkan hasil kuesioner didapatkan fakta bahwa pada responden yang menggunakan pola asuh demokratis, banyak responden yang menyatakan bahwa mereka akan langsung menangani kenakalan anak tanpa bertindak kasar. Selain itu, banyak ibu yang menyatakan bahwa mereka mempertimbangkan keinginan dan pendapat anak serta memberikan nasihat yang membangun pada anak agar berperilaku yang bertanggung jawab.

Penelitian juga menunjukkan beberapa responden lebih memilih menerapkan pola asuh otoriter dan permisif. Pola pengasuhan orang tua otoriter selalu menuntut dan mengarahkan anaknya, tetapi tidak peka dengan keadaan anak (Daron, 2005). Orangtua kadang-kadang menolak anak dan sering menerapkan hukuman (Nilam, 2010.). Hasil penerapan pola asuh ini menyebabkan anak-anak mengalami tertekan secara fisik dan psikis serta mudah putus asa (Surbakti, 2009). Pola asuh permisif menunjukkan aturan dari orang tua tidak jelas dan membiarkan anak membuat keputusan sendiri. Hal ini dapat mengakibatkan anak memiliki kepribadian yang bertindak sekehendak hati, tidak mampu mengendalikan diri dan tingkat kesadaran mereka rendah (Elizabeth, 2011)

Berdasarkan tabulasi silang antara pekerjaan dengan pola asuh didapatkan data sebagian besar responden bekerja maupun tidak bekerja memilih pola asuh demokratis. Hal ini menunjukkan pekerjaan tidak mempengaruhi pemilihan penerapan pola asuh ibu.

Berdasarkan hasil dan observasi selama penelitian didapatkan hasil bahwa sebagian besar responden memiliki pola asuh demokratis, hal ini terbukti pada saat penelitian ibu balita membawa kedua anaknya dan memperlakukan sama dan tidak dibedakan, serta para balita terlihat rukun dalam bermain dan berkomunikasi dan ibu tidak membatasi kegitan yang dilakukan oleh anaknya. 
Sibling Rivalry yaitu rasa persaingan antar saudara kandung yang disebabkan adanya kekhawatiran ia akan kehilangan kasih sayang dari orang tuanya karena kehadiran adiknya. Faktor-faktor yang mempengaruhi sibling rivalry antara lain lingkungan, yakni hubungan antara anggota keluarga terutama seorang ibu yang dituntut mampu berkomunikasi dengan anak di dalam suatu keluarga, faktor psikis anak, dan pengetahuan ibu tentang reaksi sibling rivalry (Febrianita, 2007). Seorang ibu perlu tahu bagaimana kiat-kiat menghindari sibling rivalry dan penanganannya (Judarwanto, 2005).

Pengetahuan ibu tentang sibling rivalry berkaitan dengan penerapan pola asuh ibu pada anak balita. Hal ini tebukti pada hasilpenelitian yang membuktikan hipotesis bahwa terdapat hubungan pengetahuan ibu tentang sibling rivalry dengan pola asuh ibu pada anak balita. Ibu yang berpengetahuan cukup akan lebih mengetahui bagaimana cara mengatasi sibling rivalry, misalnya dengan menghabiskan waktu bersama setiap anak sesuai prioritas dan mendengarkan perasaan anak. Hal ini sesuai dan mengarah pada penerapan pola asuh demokratis.

\section{KESIMPULAN DAN SARAN}

\section{Kesimpulan}

Sebagian besar responden memiliki pengetahuan cukup tentang sibling rivalry serta mene- rapkan pola asuh demokratis. Terdapat hubungan pengetahuan ibu tentang sibling rivalry dengan pola asuh ibu pada anak balita

\section{Saran}

Diharapkan penelitian ini dapat memberikan kontribusi teoritis bahwa pengetahuan ibu tentang sibling rivalry dengan pola asuh ibu pada anak balita anak hal yang sangat perlu untuk dipelajari lebih lanjut sehingga dapat dijadikan sebagai bahan pertimbangan dan referensi bagi peneliti lain untuk melakukan penelitian selanjutnya.

\section{DAFTAR PUSTAKA}

Desmita.(2009). Psikologi Perkembangaan. Bandung: Rosda. Fung, Daniel \&Cai YI-Ming. (2003). Mengembangkan Kepribadian Anak dengan Tepat. Jakarta: Prestasi Pustaka.

Hidayat, A. Aziz Alimul. (2010). Metode Penelitian Kebidanan dan Teknik Analisis Data. Jakarta:Salemba Medika.

Meliono dan Mubarok (2007). Dr.Suparyanto.blogspot.com Konsep Dasar pengetahuan

Markum.(2002). Ilmu Kesehatan Anak Jilid 1. Jakarta: FKUI.

Musbikin, Imam. (2005). Mendidik Anak Nakal. Yogyakarta: Mitra Pustaka.

Notoatmodjo.(2005). Metodologi Penelitian Kesehatan. Jakarta: Rineka Cipta.

Nursalam.(2003).Konsep dan Penerapan Metodologi Penelitian Ilmu Keperawatan. Jakarta: Medika Salemba.

Nilam Widyarini(2010).Relasi orang tuadan anak seri psikologi populer:Jakarta:PT Elex Media Kompetindo.

Puti Anggraeni (2008). Tandrina.blogspot.com Anak Tunggal untuk Menghindari resiko

Suherni, Sumarah (2009).Perawatan Masa Nifas: Yogyakarta, Fitramala

Thompson, June. (2003). Toddler Care (Pedoman Merawat Balita). Jakarta: Erlangga.

Tim Puspa Swara. (2001). Mengatasi Problem Psikologi Balita. Jakarta: Puspa Swara.

Yusuf, Syamsu. (2009).Psikologi Perkembangan Anak dan Remaja.Bandung: Rosda. 